\title{
Investigation of Some Water Quality Parameters of the Buriganga River
}

\author{
A. S. M. Saifullah, M. H. Kabir, A. Khatun, S. Roy and M. S. Sheikh \\ Department of Environmental Science and Resource Management, \\ Mawlana Bhashani Science and Technology University, Santosh, Tangail-1902, Bangladesh
}

\begin{abstract}
This study deals with the investigation of water quality of the Buriganga river, Dhaka. For this purpose, samples were collected from five locations of the Buriganga river of Bangladesh during wet (monsoon) and dry (winter) season in 2011 to determine the spatial distribution and temporal variation of various water quality parameters. Water samples were collected from three different depths of river. The color was light brown in wet season and slightly black to black color in dry season. The water was found slightly acidic to slightly alkaline (6.6-7.5). Water temperature ranged from $18.2^{\circ} \mathrm{C}$ (dry) to $27.04^{\circ} \mathrm{C}$ (wet). The river was found to be highly turbid both in dry and wet season. Biochemical Oxygen Demand (BOD), Electric Conductivity (EC) and Total Dissolved Solids (TDS) were found higher in the dry season compared to that of wet season, while Dissolved Oxygen (DO) was found higher in wet season. The mean values of parameters were EC: wet- $1685 \mu \mathrm{s} / \mathrm{cm}$, dry- $2250 \mu \mathrm{s} / \mathrm{cm}$; DO: wet- $4.9 \mathrm{mg} / \mathrm{L}$, dry3.7 mg/L; BOD: wet- $26.4 \mathrm{mg} / \mathrm{L}$, dry- $33.4 \mathrm{mg} / \mathrm{L}$; TDS: wet- $238 \mathrm{mg} / \mathrm{L}$, dry- $579 \mathrm{mg} / \mathrm{L}$; transparency: wet- $24.6 \mathrm{~cm}$, dry- $22.8 \mathrm{~cm}$.
\end{abstract}

Key words: Buriganga river, Dry season, Suitability, Water quality, Wet season

\section{Introduction}

Water is essential for drinking, for growing food, for washing, and it is also important for many of the pleasant recreational aspects of life (Reeve, 2002). It has become an essential commodity for the development of industrials and agriculture (Kudesia, 1990). Water is absolutely essential not only for survival of human beings, but also for animals, plants and all other living things (Razo et al., 2004). Water pollution may be caused by different municipal waste and industrial effluent. Now a day's water pollution has proven to be a very serious and very visible form of environmental contamination as water bodies are used indiscriminately as dumps (Francis, 1994).

The Buriganga river is one of the most important rivers in the country in respect to irrigation, fisheries, transportation, recreational uses and so on. The water of Buriganga river is undergoing continuous changes in terms of quality. The degradation of water quality of Buriganga has aggravated at an alarming rate as a result of increasing industrialization, urbanization and development activities. Buriganga river receives millions of litter of sewage, domestic waste, industrial and agricultural effluents. The Buriganga river is choked with industrial effluent and untreated sewage through numerous outfalls. Thousands of industrial units and sewerage lines dumping huge volumes of toxic wastes into Buriganga river increasingly polluting the water (Islam et al., 2006). These changes in water quality by industrial effluents, agricultural pollution and human waste are creating the environment unfavorable for aquatic lives. The pollution decreases the water quality of
Buriganga that may cause harm to the aquatic lives as well as agricultural and domestic uses. Keeping in mind the aims of the present experiment was to investigate some water quality parameters of the Buriganga river and to determine their suitability for fisheries and other aquatic flora and fauna.

\section{Materials and Methods}

The experiment was conducted to observe different physico-chemical properties of Buriganga river and to compare the values with the standard level of water quality parameters to know the suitability of water for fisheries and other aquatic flora and fauna.

\section{Sampling sites}

The water sample was collected from different points of Buriganga river. The sampling sites were Lalkoti Ghat, Wise Ghat, Postogola launch Ghat, Badamtoli Ghat, Babubazar Ghat. These sites were chosen because these sites are heavily polluted by different kinds of waste discharged from tannery industry, commercial sectors and households. The location of the sampling site is given in Figure 1.

\section{Sample Collection}

Water samples were collected in wet season (July, 2011) and dry season (December, 2011). Three water samples of approximately $300 \mathrm{ml}$ was collected in $500 \mathrm{ml}$ plastic bottles from three different depths viz. Surface, middle, bottom of each location. After sampling the bottles were screwed and marked with the respective identification number. 


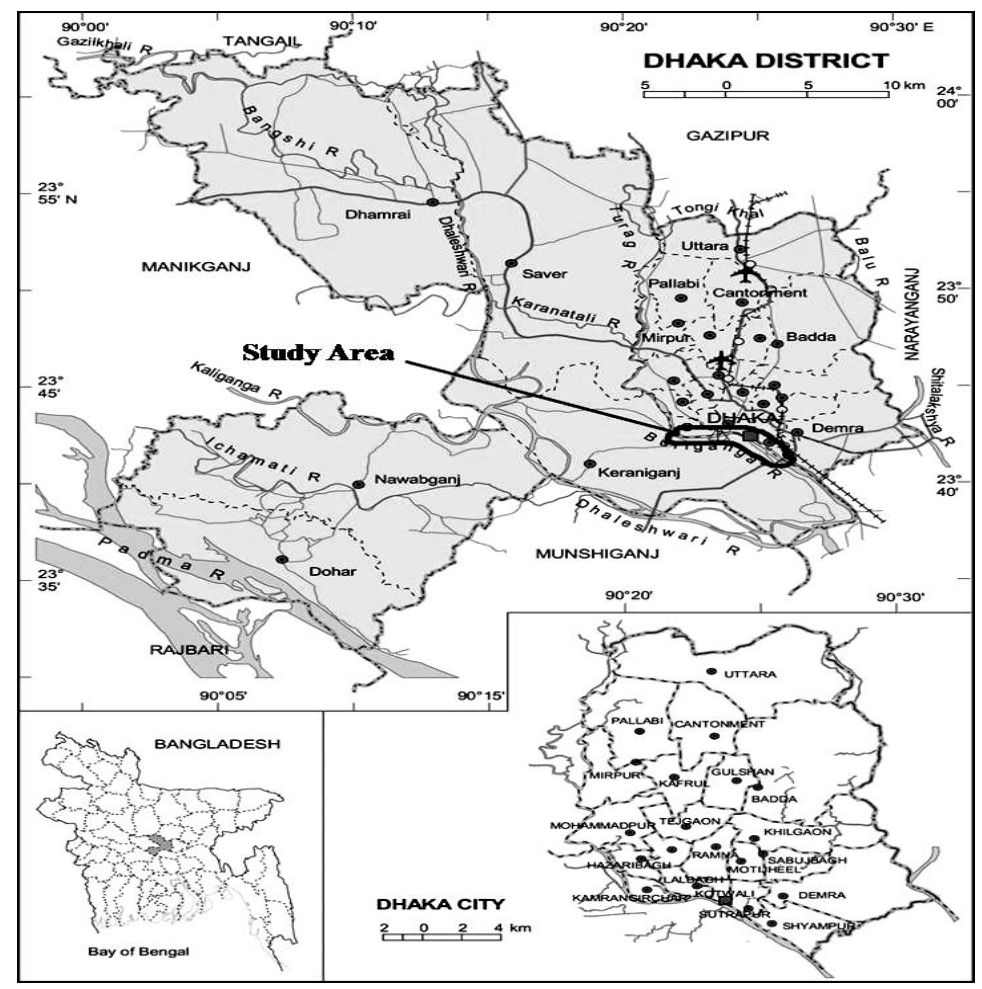

Fig. 1: Map showing the location of study area

\section{Sample analyses}

Different methods and/or instruments were used for the determination of different physico-chemical properties of water samples. The methods and/or instruments are given in Table 1.

Table 1. Methods and/or instruments used for the analysis of different parameters.

\begin{tabular}{|c|c|c|c|c|}
\hline \multirow{7}{*}{$\begin{array}{l}\text { Result } \\
\text { s and } \\
\text { Discus } \\
\text { sion }\end{array}$} & No. & Parameters & Methods/Instruments & \multirow{9}{*}{$\begin{array}{l}\text { phytopl } \\
\text { ankton } \\
\text { enriche } \\
\mathrm{d} \text { dark } \\
\text { greenis } \\
\mathrm{h} \text { blue, } \\
\text { red or }\end{array}$} \\
\hline & 1. & $\mathrm{pH}$ & pH meter & \\
\hline & 2. & Dissolve Oxygen (DO) & Titrimatric method & \\
\hline & 3. & Biological Oxygen Demand (BOD) & Titrimatric method & \\
\hline & 4. & Total Dissolve solids (TDS) & Digital TDS meter & \\
\hline & 5. & Electric conductivity (EC) & Digital EC meter & \\
\hline & 6. & Temperature & Thermometer & \\
\hline \multirow{2}{*}{$\begin{array}{l}\text { The } \\
\text { values }\end{array}$} & 7. & Transparency & Secchi Disc & \\
\hline & 8. & Color and odor & Eye observation and feeling smell & \\
\hline \multicolumn{5}{|c|}{$\begin{array}{l}\text { of temperature, pH, transparency, Electric } \\
\text { Conductivity (EC), Total Dissolved Solids (TDS), } \\
\text { Dissolved Oxygen (DO) and Biochemical Oxygen } \\
\text { Demand (BOD) of both wet and dry seasons at three } \\
\text { different denths were measured (Table } 2 \text { and Table }\end{array}$} \\
\hline
\end{tabular}
$3)$.

\section{Color and Odor}

The observed color of water of the sampling stations was light brown in wet season and slightly black to black color in dry season. This shows the sign of impairment of the natural condition of water. But

\section{Temperature}

The highest temperature has been observed at surface and subsequently decreased at lower depths. This trend was found both in dry and wet season (Table 2 and 3). During both dry and wet season, among five sites the average lowest temperature was found at 
Postogola launch Ghat $\left(26.5^{\circ} \mathrm{C}\right.$ and $16^{\circ} \mathrm{C}$ respectively in wet and dry season). In wet season, however, highest average temperature was observed at Wise Ghat $\left(28^{\circ} \mathrm{C}\right)$, whereas in dry season average temperature was found highest at Badamtoli Ghat $\left(20^{\circ} \mathrm{C}\right)$. In a study conducted by Saha et al., (2009) found highest temperature of $30^{\circ} \mathrm{C}$ during rainy season and lowest temperature of $18^{\circ} \mathrm{C}$ during winter season.

pH
The $\mathrm{pH}$ of all sampling sites was higher in dry season than the wet season. During dry season there was a little difference in average $\mathrm{pH}$ ranging from 7.47 at Lalkoti Ghat and Postogola launch Ghat to 7.83 at Badamtoli Ghat. During wet season the lowest average $\mathrm{pH}$ was also found at Postogola launch Ghat (pH- 6.63) and highest at Babubazar Ghat (7.13). Saha et al., (2009) found higher pH of 7.16 in Sowari ghat during winter compared to rainy season (6.25 in Shmashan ghat). The $\mathrm{pH}$ ranging from 6-9 is suitable for the existence of most biological life (Metcalf and Eddy, 2003).

Table 2. Results of physico-chemical parameters during dry season

\begin{tabular}{|c|c|c|c|c|c|c|c|c|}
\hline Stations & Layers & $\mathrm{pH}$ & $\begin{array}{c}\text { TDS } \\
(\mathrm{mg} / \mathrm{l})\end{array}$ & $\begin{array}{c}\text { EC } \\
(\mu \mathrm{S} / \mathrm{cm})\end{array}$ & $\begin{array}{l}\text { Temp. } \\
\left({ }^{\circ} \mathrm{C}\right)\end{array}$ & $\begin{array}{c}\mathrm{DO} \\
(\mathrm{mg} / \mathrm{l})\end{array}$ & $\begin{array}{l}\text { BOD } \\
(\mathrm{mg} / \mathrm{l})\end{array}$ & $\begin{array}{c}\text { Transparency } \\
\text { (cm) }\end{array}$ \\
\hline \multirow[t]{3}{*}{ Lalkoti Ghat } & Surface & 7.1 & 510 & 2100 & 20.0 & 2.2 & 28.5 & \multirow{3}{*}{20} \\
\hline & Middle & 7.6 & 625 & 2145 & 18.9 & 2.0 & 28.9 & \\
\hline & Bottom & 7.7 & 650 & 2167 & 17.7 & 1.8 & 29.0 & \\
\hline \multirow[t]{3}{*}{ Wise Ghat } & Surface & 7.4 & 450 & 2236 & 18.0 & 2.9 & 38.9 & \multirow{3}{*}{24} \\
\hline & Middle & 7.6 & 466 & 2251 & 17.7 & 3.6 & 38.9 & \\
\hline & Bottom & 7.8 & 498 & 2289 & 16.4 & 1.8 & 40.7 & \\
\hline \multirow{3}{*}{$\begin{array}{l}\text { Postogola } \\
\text { launch } \\
\text { Ghat }\end{array}$} & Surface & 7.2 & 641 & 2236 & 17.2 & 2.6 & 39.0 & \multirow{3}{*}{18} \\
\hline & Middle & 7.3 & 671 & 2289 & 16.2 & 2.9 & 39.3 & \\
\hline & Bottom & 7.9 & 678 & 2289 & 15.6 & 3.1 & 41.9 & \\
\hline \multirow{3}{*}{$\begin{array}{l}\text { Badamtoli } \\
\text { Ghat }\end{array}$} & Surface & 7.8 & 438 & 2687 & 21.6 & 4.3 & 27.9 & \multirow{3}{*}{26} \\
\hline & Middle & 7.9 & 490 & 2770 & 20.4 & 5.2 & 28.6 & \\
\hline & Bottom & 7.8 & 499 & 2799 & 18.9 & 5.9 & 29.2 & \\
\hline \multirow{3}{*}{$\begin{array}{l}\text { Babubazar } \\
\text { Ghat }\end{array}$} & Surface & 7.3 & 670 & 2456 & 19.7 & 4.2 & 28.2 & \multirow{3}{*}{25} \\
\hline & Middle & 7.6 & 698 & 2458 & 18.4 & 3.7 & 29.3 & \\
\hline & Bottom & 7.6 & 710 & 2570 & 16.8 & 3.1 & 33.6 & \\
\hline
\end{tabular}

\section{Water Transparency}

In wet season, among the five ghats (stations) the highest transparency was found in Babubazaar Ghat $(29 \mathrm{~cm})$ and lowest in Lalkoti Ghat $(18 \mathrm{~cm})$, whereas in dry season the value was found highest in Badamtoli Ghat $(26 \mathrm{~cm})$ and lowest in Postogola launch Ghat (18cm). Rahman and Rana (1992) stated that the transparency of productive water bodies should be $40 \mathrm{~cm}$. So, it can be easily understood that the studied river is unsuitable for the fisheries during both wet and dry season.

\section{Electric Conductivity (EC)}

Among the five locations, in wet season, the highest average EC of $1780 \mu \mathrm{S} / \mathrm{cm}$ was found at Wise Ghat and lowest was found at Postogola launch Ghat (1559 $\mu \mathrm{S} / \mathrm{cm})$. In dry season, the highest average EC was found at Badamtoli Ghat $(2752 \mu \mathrm{S} / \mathrm{cm})$ and lowest was found at Lalkoti Ghat $(2137 \mu \mathrm{S} / \mathrm{cm})$. The EC 
values at different location are given in Table 2 and 3. Alam et al. (2007) has found higher EC in dry season (805 $\mu \mathrm{S} / \mathrm{cm})$ compared to wet season $(84 \mu \mathrm{S} / \mathrm{cm})$. In the dry season, the total volume of water decreases, as a result the conductivity increases.

\section{Total Dissolved Solids (TDS)}

The TDS values were found highest in dry season compared wet season. In dry season, average TDS values ranged from $471 \mathrm{mg} / \mathrm{l}$ (Wise Ghat) to $692 \mathrm{mg} / \mathrm{l}$ (Badamtoli Ghat). In wet season, the highest average TDS value was found at Badamtoli Ghat (324 mg/l) lowest at Postogola launch Ghat $(170 \mathrm{mg} / \mathrm{l})$. The high
TDS value of the water is due to different sewage, domestic waste, industrial and agricultural effluents.

\section{Dissolved Oxygen (DO)}

Dissolved Oxygen values have been found highest in wet season compared dry season. During dry season the lowest average DO value was found at Lalkoti Ghat $(2 \mathrm{mg} / \mathrm{l})$, whereas the highest average value was found at Badamtoli Ghat $(5.13 \mathrm{mg} / \mathrm{l})$. On the other hand, during wet season the lowest average DO value was also found at Lalkoti Ghat $(4.6 \mathrm{mg} / \mathrm{l})$ but highest at Babubazar Ghat $(5.4 \mathrm{mg} / \mathrm{l})$. Rahman and Rana (1996) found DO at Hazaribag area of Buriganga river as low as $2 \mathrm{mg} / \mathrm{l}$ in dry season.

Table 3. Results of physico-chemical parameters during wet season.

\begin{tabular}{|c|c|c|c|c|c|c|c|c|}
\hline Stations & Layers & $\mathrm{pH}$ & $\begin{array}{l}\mathrm{TDS} \\
(\mathrm{mg} / \mathrm{l})\end{array}$ & $\begin{array}{c}\mathrm{EC} \\
(\mu \mathrm{S} / \mathrm{cm})\end{array}$ & $\begin{array}{l}\text { Temp. } \\
\left({ }^{\circ} \mathrm{C}\right)\end{array}$ & $\begin{array}{c}\mathrm{DO} \\
(\mathrm{mg} / \mathrm{l})\end{array}$ & $\begin{array}{l}\mathrm{BOD} \\
(\mathrm{mg} / \mathrm{l})\end{array}$ & $\begin{array}{c}\text { Transparency } \\
\text { (cm) }\end{array}$ \\
\hline \multirow[t]{3}{*}{ Lalkoti Ghat } & Surface & 6.1 & 181 & 1538 & 28.7 & 6.0 & 27.0 & \multirow{3}{*}{18} \\
\hline & Middle & 6.5 & 184 & 1590 & 26.2 & 4.8 & 27.3 & \\
\hline & Bottom & 6.9 & 185 & 1607 & 25.1 & 3.0 & 29.6 & \\
\hline \multirow[t]{3}{*}{ Wise Ghat } & Surface & 6.2 & 210 & 1670 & 30.5 & 6.5 & 28.9 & \multirow{3}{*}{27} \\
\hline & Middle & 6.5 & 245 & 1681 & 27.5 & 4.8 & 28.5 & \\
\hline & Bottom & 6.7 & 250 & 1990 & 26.0 & 3.9 & 29.3 & \\
\hline \multirow{3}{*}{$\begin{array}{l}\text { Postogola } \\
\text { launch Ghat }\end{array}$} & Surface & 6.4 & 150 & 1520 & 29.8 & 5.8 & 26.6 & \multirow{3}{*}{22} \\
\hline & Middle & 6.6 & 171 & 1578 & 25.5 & 3.9 & 27.3 & \\
\hline & Bottom & 6.9 & 190 & 1580 & 24.3 & 4.2 & 29.6 & \\
\hline \multirow{3}{*}{$\begin{array}{l}\text { Badamtoli } \\
\text { Ghat }\end{array}$} & Surface & 6.1 & 288 & 1710 & 31.5 & 6.2 & 17.3 & \multirow{3}{*}{27} \\
\hline & Middle & 6.6 & 325 & 1755 & 27.3 & 4.7 & 19.8 & \\
\hline & Bottom & 6.8 & 360 & 1788 & 23.4 & 4.0 & 22.9 & \\
\hline \multirow{3}{*}{$\begin{array}{l}\text { Babubazar } \\
\text { Ghat }\end{array}$} & Surface & 7.0 & 230 & 1620 & 28.9 & 6.3 & 26.9 & \multirow{3}{*}{29} \\
\hline & Middle & 7.1 & 298 & 1662 & 26.3 & 5.8 & 27.5 & \\
\hline & Bottom & 7.3 & 310 & 1989 & 24.6 & 4.2 & 28.1 & \\
\hline
\end{tabular}

\section{Biochemical Oxygen Demand (BOD)}

Unlike TDS and EC the BOD of water samples of five locations were found higher in dry season compared to wet season. Among the five spots the highest average BOD in dry season was found at Wise Ghat and Postogola launch Ghat (40 mg/l), while the lowest value was found at Badamtoli Ghat
(28.5 mg/l). Similarly, in wet season the highest average BOD was found at Wise Ghat $(30 \mathrm{mg} / \mathrm{l})$ and the lowest average BOD was found at Badamtoli Ghat $(20 \mathrm{mg} / \mathrm{l})$. Unpolluted waters typically have BOD values of $2 \mathrm{mg} / \mathrm{l}$ or less (Chapman, 1996). The normal range of BOD for good water quality is 5-6 $\mathrm{mg} / \mathrm{l}$ (Huq and Alam, 2005). Higher BOD of the 
Buriganga river is the result of pollution with various organic and chemical pollutants.

\section{Comparison of data with standard values for fisheries}

The average values of all investigated water quality parameters were compared with standard values to determine the suitability of water for fisheries (Table
4). High BOD level clearly indicates that the River Buriganga was polluted with the organic chemical and bacterial pollutants. The BOD was unsuitable for fisheries in wet and dry season. BOD value exceeded the standard limit that causes unfavorable condition for fisheries. The $\mathrm{pH}$ was, however, within the range of standard value. The DO content in dry season was lower than the standard limit for fisheries.

Table 4. Comparison of investigated data with standard values for fisheries.

\begin{tabular}{|c|c|c|c|}
\hline \multirow{2}{*}{ Parameters } & $\begin{array}{c}\text { Bangladesh Standard for } \\
\text { Fisheries } \\
(\mathrm{EQS}, 1997)\end{array}$ & \multicolumn{2}{|c|}{$\begin{array}{c}\text { Investigated Water Quality } \\
\text { (average value) }\end{array}$} \\
\cline { 3 - 4 } & $6.5-8.5$ & 6.6 & Wet season season \\
\hline $\mathrm{pH}$ & $4.0-6.0$ & 4.9 & 7.5 \\
\hline $\mathrm{DO}(\mathrm{mg} / \mathrm{I})$ & $(-)$ or below 26.4 & 33.4 \\
\hline $\mathrm{BOD}(\mathrm{mg} / \mathrm{I})$ & 500 & 238 & 579 \\
\hline $\mathrm{TDS}(\mathrm{mg} / \mathrm{l})$ & $800-1000$ & 1685 & 2250 \\
\hline EC $(\mu \mathrm{s} / \mathrm{cm})$ & 25 & 27.04 & 18.2 \\
\hline Temperature $\left({ }^{\circ} \mathrm{C}\right)$ & 40 & 24.6 & 22.8 \\
\hline Transparency $(\mathrm{cm})$ & & & \\
\hline
\end{tabular}

Lower DO content may be due to the decomposition of different organic wastes by micro-organisms. The water temperature (wet season) indicates almost suitability for fish habitat and breeding as well. High values of EC, TDS and lower values of transparency indicate the unsuitability of water for fish production.

\section{Conclusion}

Rampant disposal of municipal and industrial wastes is polluting the water of Buriganga river. With the pollution of water bodies by chemical and organic wastes the oxygen concentration in this water body becomes very low at some locations of the river. The pollution of water leads to either death or migration of fishes living there to some other places. As a result, fish population in this river has drastically decreased in recent times. The pollution problem cannot be solved in a short period. Thus, it needs to continuous efforts to control the pollution problem.

\section{References}

Alam, M. J. B.; Islam, M. R.; Muyen, Z.; Mamun, M. and Islam, S. 2007. Water Quality Parameters along Rivers. Int. J. Environ. Sci. Tech., 4 (1): 159-167.

Chapman, D. 1996. Water Quality Assessment. A Guide to the Use of Biota, Sediments and Water in Environmental Monitoring, $2^{\text {nd }}$ Edition, UNESCO/WHO/UNEP.

Das, B. 1997. Fisheries and Fisheries Resources Management. Bangla Academy, Dhaka, Bangladesh, pp. 153-155.

EQS (Environmental Quality Standard). 1997. Bangladesh Gazette, registered nr. DA- 1, Ministry of Environment, Government of Bangladesh.

Francis, C. H. 1994. Accumulation and disponibilidad de metals pesados en suelos regados con agus residualses en Distrito de Riego 03, Tula, Hgo. Rev. Inter. Contam. Ambient, 10: 15-21. 
Huq, S. M. I. and Alam, M. D. 2005. A Handbook on analyses of Soil, Plant and Water. BACERDU, University of Dhaka. pp. 246.

Islam, M. M.; Akhtar, M. K. and Masud, M. S. 2006. Prediction of environmental flow to improve the water quality in the river Buriganga. Proceedings of the $17^{\text {th }}$ IASTED International Conference on Modelling and Simulation, Montreal, QC, Canada.

Kudesia, V. P. 1990. Industrial Pollution. Progati Prokashan. India.

Metcalf and Eddie. 2003. Wastewater Engineering Treatment and Reuse. Forth Edition. New York, USA: McGraw Hill.

Rahman, M. R. and Rana, M. Y. 1992. Management of Buriganga River Water Quality Under Alternative Scenarios. Final Report. R02/95. IFCDR. BUET.
Rahman, M. R. and Rana, M. Y. 1996. Pollution Assimilation Capacity of Buriganag River. $J$. of Civil Eng., 24(1): 85-95.

Razo, I.; Carrizales, L.; Castro, J.; Diaz, B. F.; and Moroy, M. 2004. Arsenic and Heavy Metal Pollution of Soil, Water and Sediments in a semi-arid Climate Mining area in Mexico. Water, air, Soil Poll., 152 (1-4): 129-152.

Reeve, N. 2002. Introduction to Environmental analysis. John Willey and Sons limited, England.

Saha, M. L., Khan, M. R.; Ali, M. and Hoque S. 2009. Bacterial Load and Chemical Pollution Level of the River Buriganga, Dhaka, Bangladesh. Bangladesh J. Bot., 38(1): 8791. 